\title{
Effects of the Antimicrobial Peptide OH-CATH on Escherichia coli
}

\author{
CHEN Xin-xin ${ }^{1,2}$, YU Guo-yu ${ }^{1,3}$, ZHAN Yan ${ }^{2}$, ZHANG Yun ${ }^{1}$, SHEN Ji-hong ${ }^{4, *}$, LEE Wen-hui ${ }^{1, *}$ \\ (1. Key Laboratory of Animal Models and Human Diseases Mechanisms, Kunming Institute of Zoology, the Chinese Academy of Sciences, \\ Kunming Yunnan 650223, China; 2. Cell Biology and Genetics Section of Kunming Medical College, Kunming Yunnan 650031, China; \\ 3. Biochemistry Section of Kunming Medical College, Kunming Yunnan 650031, China; 4. Department of Urology, the First Affiliated \\ Hospital of Kunming Medical College, Kunming Yunnan 650032, China)
}

\begin{abstract}
OH}-\mathrm{CATH}$ is a novel cathelicidin identified from king cobra. It showed strong antibacterial activity against various bacteria in the presence of $1 \% \mathrm{NaCl}$ and no haemolytic activity toward human red blood cells even at a high concentration. OH-CATH might serve as model molecules for the development of antimicrobial drugs. Understanding the action mechanism of OH-CATH and the reason for its selectivity against microbes is very important for this purpose. The bactericidal effect of the king cobra antimicrobial peptide OH-CATH on Gram-negative Escherichia coli (ATCC 25922) is observed by scanning electron microscopy (SEM) and transmitted electron microscopy (TEM). The SEM and TEM results suggested that the bactericidal mechanism of OH-CATH against Escherichia coli happened in three steps. Firstly, OH-CATH attached to the negatively charged bacterial wall by positively charged amino acid residues. In the second step, the accumulated OH-CATH aggregated and damaged the bacteria membrane in a pore-forming manner. In the last step, with the damage of cell permeability, the contents of the cells were released and eventually cells died.
\end{abstract}

Key words: Antimicrobial peptide; OH-CATH; Escherichia coli; Electron microscopy

\section{抗菌肽 OH-CATH 对大肠杆菌 Escherichia coli 的作用}

\author{
陈欣欣 ${ }^{1,2}$, 余果宇 ${ }^{3}$, 张 彦 $^{2}$, 张 云 $^{1}$, 申吉弜 , * $^{*}$, 李文辉 ${ }^{1, *}$
}

(1. 中国科学院动物模型与人类疾病机理重点实验室, 云南 昆明 $650223 ; 2$. 昆明医学院 细胞生物学及遗传学教研室, 云南 昆明 650031；3. 昆明医学院 生物化学教研室, 云南 昆明 650031；4. 昆明医学院第一附属医院 泌尿外科, 云南 昆明 650032)

摘要: OH-CATH是眼镜王蛇中新发现的cathelicidin家族抗菌肽。它在 $1 \% \mathrm{NaCl}$ 存在的条件下对多种细菌都有 较强的抗菌活性, 同时, 在高浓度下对人红细胞无溶血活性。OH-CATH是开发新型抗菌药物的优良模板。阐明 OH-CATH的作用机理及其对微生物的选择性, 对研发以 OH-CATH为先导结构的药物研发有十分重要的意义。本 文利用扫描电镜以及透射电镜对 OH-CATH与革兰氏阴性菌一大肠杆菌ATCC 25922 相互作用的效应研究。结果揭 示: OH-CATH对大肠杆菌的作用涉及到 3 个步骤。首先, OH-CATH借助其带正电的氨基酸残基附着到细菌带负电 荷的细胞壁; 然后, 附着的OH-CATH在达到一定浓度后发生聚集, 以孔道形成的方式破坏细菌的膜结构; 最终, 由于细菌膜的损坏, 膜的渗透性被破坏, 胞内内含物释放造成细菌死亡。

关键词: 抗菌肽; OH-CATH; 大肠杆菌; 电镜

中图分类号: Q514.3; Q939.92 文献识码: A

文章编号：0254-5853-(2009)02-0171-07

It has been widely recognized that antimicrobial peptides play an important role in protecting organisms from invading of microorganisms (Boman, 1991, 1995; Zasloff, 1992; Nicolas \& Mor, 1995). Antimicrobial peptides have successfully been isolated from plants
(Broekaert et al, 1995), invertebrates (Vizioli \& Salzet, 2002), vertebrates (Hancock \& Lehrer, 1998; Li et al, 2001), and human (Harder et al, 1997; Li et al, 1995; Li et al, 2001; Zhao et al, 2008a,b). Because of the growing problem of multi-drug resistant pathogenic organisms,

Received date: 2008-11-26; Accepted date: 2009-02-13

收稿日期：2008-11-26; 接受日期：2009-02-13

基金项目：国家自然科学基金（30670412），中国科学院重要方向项目（KSCX2-YW-R-088）; 云南省自然科学基金资助项目 (2005PY01-23; 2006PT08-1; 2006C0047Q)

*通讯作者(Corresponding authors), 申吉泓, Tel: 0871-5324888-2402, E-mail: kmsjh99@yahoo.com.cn; 李文辉, Tel: 0871-5194279, E-mail: leewh@mail.kiz.ac.cn

第一作者简介: 陈欣欣 (1972-), 女, 硕士研究生。研究方向: 生物化学与分子生物学 
there is increased interest in the pharmacological application of antimicrobial peptides to treat infection. Currently, large efforts are being made to increase the potency and specificity of these peptides so that they become toxic to microbes and not to humans. In order to achieve this goal in an efficient manner, it is important to elucidate the mechanism of action of these peptides and the reason for their selectivity against microbes (da Silva \& Teschke, 2003).

Cathelicidins are cationic host defense peptides that play an important role in innate immune system. Members of the cathelicidin family all include N-terminal signal peptides and proregions highly homologous to cathelin, a cathepsin $\mathrm{L}$ inhibitor, then followed by highly divergent C-terminal antimicrobial domains (Bals \& Wilson, 2003; Lehrer \& Ganz, 2002). Up to now, most of the identified cathelicidins were from mammalian species (Zanetti et al, 1990, 1993, 1995). Five cathelicidins termed fowlicidin-1, 2, 3, B1 and myeloid antimicrobial peptide 27 were characterized from chicken (Xiao et al, 2006; Goitsuka et al, 2007). Cathelicidins were also found in fish species of Atlantic hagfish Myxine glutinosa, rainbow trout Oncorhynchus mykiss and Atlantic salmon Salmo salar. Hagfish cathelicidins were considered as ancient members of the cathelicidin family (Chang et al, 2005, 2006; Uzzell et al, 2003).

Recently, we cloned three cDNA sequences coding for elapid cathelicidins from constructed venom gland cDNA libraries of Naja atra, Bungarus fasciatus and Ophiophagus hannah. The open reading frames of the cloned elapid cathelicidins were all composed of 576bp and coded for 191 amino acid residue protein precursors. Each of the deduced elapid cathelicidin has a 22 amino-acid-residue signal peptide, a conserved cathelin domain of 135 amino acid residues and a mature antimicrobial peptide of 34 amino acid residues. Unlike the highly divergent cathelicidins in mammals, the nucleotide and deduced protein sequences of the three cloned elapid cathelicidins were remarkably conserved. $\mathrm{OH}-\mathrm{CATH}$, the deduced mature cathelicidin from king cobra, showed strong antibacterial activity against various tested bacteria with minimal inhibitory concentration of $1-20 \mathrm{~g} / \mathrm{mL}$ in the presence of $1 \% \mathrm{NaCl}$. Meanwhile, the peptide showed no haemolytic activity toward human red blood cells even at a high dose of 200 $\mathrm{g} / \mathrm{mL}$. Elapid cathelicidins might serve as model molecules for the development of antimicrobial drugs (Zhao et al, 2008c).
In the present work, the bactericidal effect of the king cobra antimicrobial peptide $\mathrm{OH}-\mathrm{CATH}$ on Gram-negative Escherichia coli (ATCC 25922) is observed by scanning electron microscopy (SEM) and transmitted electron microscopy (TEM). The bactericidal mechanism of OH-CATH against E. coli was reported based on the obtained SEM and TEM images.

\section{Materials and Methods}

\subsection{Materials}

Escherichia coli ATCC 25922 was obtained from The First Affiliated Hospital of Kunming Medical College, China. Yeast extract and Tryptone for bacterial culture were products of Oxoid Ltd. Company (England). All other reagents used were analytic grade from commercial sources.

\subsection{Peptide synthesis}

King cobra antimicrobial peptide $\mathrm{OH}-\mathrm{CATH}$ with amino acid sequence of KRFKKFFKKLKNSVKKRAKKFFKKPRVIGVSIPF was synthesized by solid-phase synthesis on an Applied Biosystems Model 433A peptide synthesizer according to the manufacturer's standard protocols. After cleavage and side-chain deprotection, the crude synthetic peptide was purified on a Vydac 218 TP510 C18 reverse phase-HPLC column $(25 \times 1 \mathrm{~cm}$. Separations Group, Hesperia, CA, USA) and eluted at a flow rate of $2 \mathrm{~mL} / \mathrm{min}$ by a linear gradient of acetonitrile in $0.1 \%$ trifluoroacetic acid in water. Identity of the peptide was confirmed by automated Edman degradation with a protein sequencer and mass spectrometry analysis. Fast atom bombardment-mass spectrometry was carried out on an Autospec-3000 spectrometer, equipped with a high-field magnet (Lee et al, 2005). The purity of the synthetic peptide was $>95 \%$ and then used for evaluating biological activities.

\subsection{Sample preparation for SEM and TEM}

Overnight culture of $E$. coli cells $\left(\mathrm{OD}_{600 \mathrm{~nm}}=1.2\right)$ in LB medium was diluted 100 times with fresh LB medium and gave a total culture volume of $20 \mathrm{~mL}$. Then, the bacteria were continue to culture at $37^{\circ} \mathrm{C}$ for additional 4 hours to get mid-logarithmic-phase organisms $\left(\mathrm{OD}_{600 \mathrm{~nm}}=0.7\right)$. OH-CATH was added to the culture medium to reach a final concentration of $12 \mathrm{~g} / \mathrm{mL}$ and cultured under the conditions as mentioned above. At different time intervals, aliquots were removed and optical density was measured at $600 \mathrm{~nm}$ for both $\mathrm{OH}-\mathrm{CATH}$ treated and untreated samples. The samples prepared for SEM and TEM were as follows: 1) SEM samples, aliquots of $1 \mathrm{~mL}$ culture medium at various 
culture times were removed to $1.5 \mathrm{~mL}$ eppendorf tubes and centrifuged at room temperature for 4 minutes $(2000$ rpm). After discard the supernatant, $1 \mathrm{~mL}$ fresh LB medium were added and vortex thoroughly to wash the bacterial pellets and centrifuged again at $2000 \mathrm{r} / \mathrm{min}$ for 4 minutes. After carefully removal of the supernatant, bacterial cells were chemically pre-fixed with $3.5 \%$ glutaraldehyde in $0.1 \mathrm{~mol} / \mathrm{L}$ PBS buffer $(\mathrm{pH} 7.4)$ at $4^{\circ} \mathrm{C}$ overnight. The pre-fixed bacterial cells were collected on a poly lysine treated microscopy coverslips and washed three times with Milli-Q water. The cells on the coverslips were post-fixed with $2 \%$ osmic acid for 1 hour and subsequently dehydrated with $30 \%, 50 \%, 70 \%, 80 \%$, $90 \%, 100 \%$ graded ethanol and acetone series. The samples were lyophilized, coated with $\mathrm{Pa} / \mathrm{Pt}$ and examined by SEM on a Hitachi $300-\mathrm{N}$ instrument. 2) TEM samples, aliquots of $1.5 \mathrm{~mL}$ culture medium at various culture times were removed to $2 \mathrm{~mL}$ eppendorf tubes and centrifuged at room temperature for 4 minutes $(2000 \mathrm{r} / \mathrm{min})$. After discard the supernatant, $1.5 \mathrm{~mL}$ fresh LB medium were added and vortex thoroughly to wash the bacterial pellets and centrifuged again at $2000 \mathrm{r} / \mathrm{min}$ for 4 minutes. After carefully removal of the supernatant, bacterial cells were chemically pre-fixed with $3.5 \%$ glutaraldehyde in $0.1 \mathrm{~mol} / \mathrm{L}$ PBS buffer $(\mathrm{pH} 7.4)$ at $4^{\circ} \mathrm{C}$ overnight. The pre-fixed bacterial cells were post-fixed with $1 \%$ osmic acid for 1 hour and subsequently dehydrated with $30 \%, 50 \%, 70 \%, 80 \%, 90 \%, 100 \%$ graded acetone series. Epoxy resin (Epon-618) was used to embed the post-fixed bacterial samples for 12-16 hours at room temperature. Ultra thin section of the embedded samples were prepared by LKB-II Ultracut instrument and double stained with uranyl acetate and lead citrate. The samples were lyophilized then examined by transmitted electron microscopy on a Hitachi TEM-1011 instrument. The optical density (OD) at 600 $\mathrm{nm}$ was recorded to evaluate the growth of the bacteria.

\section{Results and Discussion}

$\mathrm{OH}-\mathrm{CATH}$ is a new member of cathelicidin antimicrobial peptides characterized from Elapidae king cobra snake. Our previously results indicated that the peptide have a MIC value of $2 \mathrm{~g} / \mathrm{mL}$ and $8 \mathrm{~g} / \mathrm{mL}$ against $E$. coli ATCC 25922 under $\mathrm{NaCl}$-free and in the presence of $1 \% \mathrm{NaCl}$ conditions, respectively. Meanwhile, OH-CATH showed no hemolytic activity toward human red blood cells up to $200 \mathrm{~g} / \mathrm{mL}$, suggestion that this molecular might be served as a good model for the developing of new antibacterial agents (Zhao et al, 2008c). Understanding the antibacterial mechanism of OH-CATH against bacterial pathogens should do a great help for the design of more potent antibacterial and better specificity for OH-CATH derived peptide(s) against microbes while maintain weak cytotoxic to human cells. Recently, atomic force microscope (AFM) has been used to study antimicrobial peptide mechanisms both on model membrane and intact cells. AFM is a powerful imaging tool capable of achieving high resolution images under physiological conditions and gives 3-D reconstruction images ( $\mathrm{Li}$ et al, 2007). Nevertheless, SEM and TEM are still used to investigate the mechanisms of antimicrobial peptides with microbes (Matsuzaki et al, 1997).

Gram-negative E. coli ATCC 25922 strain was widely used as a control for evaluation of antibacterial activity for antibacterial peptides. AFM images of E. coli ATCC 25922 indicated that they showed characteristic rod shape with distinctive peritrichous flagella and pili structure ( $\mathrm{Li}$ et al, 2007). Previously, we have demonstrated that OH-CATH have a MIC value of 2 $\mathrm{g} / \mathrm{mL}$ in $\mathrm{NaCl}$-free $\mathrm{LB}$ media with bacterial inoculation of $5 \times 10^{5} \mathrm{cfu} / \mathrm{mL}$ at $37^{\circ} \mathrm{C}$ for 16 hours (Zhao et al, 2008c). In our experiment conditions, one absorption unit at $600 \mathrm{~nm}$ approximately equal to $1 \times 10^{9} \mathrm{cfu} / \mathrm{mL}$. To investigate the interaction of OH-CATH with $E$. coli 25922 , a lower OH-CATH concentration of $12 \mathrm{~g} / \mathrm{mL}$ was used to treat E. coli 25922 at a beginning concentration of about $7 \times 10^{8} \mathrm{cfu} / \mathrm{mL}$ and incubated for 21 hours. It should be noted even the OH-CATH concentration used in the present work was 6 times higher than its MIC for E. coli $25922(12 \mathrm{~g} / \mathrm{mL}$ vs $2 \mathrm{~g} / \mathrm{mL})$, but the bacterial inoculation of E. coli 25922 in the present work was 1000 times higher than that for MIC determination $\left(7 \times 10^{8} \mathrm{cfu} / \mathrm{mL}\right.$ vs $\left.5 \times 10^{5} \mathrm{cfu} / \mathrm{mL}\right)$. Obviously, the $\mathrm{OH}-\mathrm{CATH}$ concentration used in the present work was comparatively lower at a beginning bacterial inoculation of $7 \times 10^{8} \mathrm{cfu} / \mathrm{mL}$ and allow us to investigate the time-dependent interaction of OH-CATH against $E$. coli ATCC 25922. E. coli ATCC 25922 growth kinetics of both OH-CATH treated and un-treated bacterial cells were shown in Tab. 1. At each determined incubation intervals, lower antibacterial dosage treated samples showed a declined bacterial cell growth compared with un-treated samples, indicating that $\mathrm{OH}-\mathrm{CATH}$ do affect the E. coli ATCC 25922 growth. The determined OD values of OH-CATH treated samples at different incubation intervals also suggested that the $\mathrm{OH}-\mathrm{CATH}$ at the fixed concentration of $12 \mathrm{~g} / \mathrm{mL}$ could not fully kill the 
tested bacteria and the bacteria could still grow.

SEM images suggested that the untreated E. coli cells (Fig. 1A,B) had a smooth surface with average size of $0.5 \times 2^{-4} \mathrm{~m}$. The arrows in both Fig. $1 \mathrm{~A}$ and $1 \mathrm{~B}$ indicated the flagella or pili connections between $E$. coli cells. After treated with lower concentration of $\mathrm{OH}-\mathrm{CATH}$ for 1 hour, there are litter obviously morphological changes for E. coli cells (Fig. 1C). Pore-forming and morphological changes were observed for $E$. coli cells being treated with $\mathrm{OH}-\mathrm{CATH}$ for 2 hours, lysis of $E$. coli cells and release of fluid and debris could be observed (Fig. 1D). After treated with OH-CATH for 6 hours, elongation of cells $(>9 \mu \mathrm{m})$ and shorten cells $(<1 \mu \mathrm{m})$ were clearly observed (Fig. 1E). Meanwhile, collapse of E. coli cell outer membrane and release of bacterial fluid could be seen as indicated by the arrows in Fig. 1F. The average pore sizes of bacteria treated with $\mathrm{OH}-\mathrm{CATH}$ were measured to be $100-300 \mathrm{~nm}$ (figure not shown). After treated with lower concentration of $\mathrm{OH}-\mathrm{CATH}$ for 21 hours, the bacteria cells continuously grew (Tab. 1) and the morphological changes of the growing cells (Fig. 1G, H) were obviously different from the cells untreated with antibacterial peptide (Fig. 1A,B). The most obvious differences were included more fiber-like connection among cells as indicated by arrows in Fig $1 \mathrm{G}$, elongation of cell body and cell surface becoming roughness for the growing cells (Fig. 1H). These images indicated that the cell growth is affected by the antibacterial peptide.

TEM images suggested that the untreated E. coli cells had normal structure (Fig. 1A). The ultra-structure of an untreated E. coli cell was shown in Fig. 1B where outer membrane, periplasm and cytoplasmic membrane could be seen. After treated with lower concentration of $\mathrm{OH}-\mathrm{CATH}$ for 2 hours, some bacterial cells showed morphological changes, like bleb-like structures, were observed (Fig. 2C, D). The arrow in Fig. 2C indicated that periplasmic and/or cytoplasmic fluid was released from damaged cells. The OH-CATH treated cells showed cytoplasmic membrane extraction resulted in the separation of outer membrane and cytoplasmic membrane as indicated by the arrows in Fig. 2D. It should be noted that SEM images of bacterial cells after treated with OH-CATH for 1 or 2 hours showed little morphological changes (Fig. 1C, D). Thus, SEM and TEM results of bacterial cells treated with $\mathrm{OH}-\mathrm{CATH}$ for 1-2 hours suggested that $\mathrm{OH}-\mathrm{CATH}$ should bind to the bacterial wall and reach a certain concentration then aggregate to act in a pore-formation manner to damage the cell membrane and release the cell fluid. After treated with OH-CATH for 6 hours (Fig. 2E, F), many bacterial cells were damaged by $\mathrm{OH}-\mathrm{CATH}$ and bleb-like structure existed in many cells (Fig. 2E). Formation of bacterial ghost, which contains intact bacterial envelope, after treated with $\mathrm{OH}-\mathrm{CATH}$ was indicated by the arrow in Fig. 2E. Bacterial ghost was formed by $\mathrm{OH}-\mathrm{CATH}$ in a pore-forming manner and the opening of the bacteria was indicated by an arrow in Fig. 2F. After treated with lower concentration of OH-CATH for 21 hours (Fig. 2G, H), some new growing bacteria cells showed normal structure, together with damaged cell debris (Fig. 2G). The arrows in Fig. $2 \mathrm{H}$ indicated the opening of the damaged cells.

In conclusion, our results indicated that $\mathrm{OH}-\mathrm{CATH}$ and Gram-negative E. coli ATCC 25922 interactions might happen in three steps. At beginning, OH-CATH attached to the negatively charged bacterial wall by positively charged amino acid residues. In the second step, with the attached $\mathrm{OH}-\mathrm{CATH}$ reached a certain concentration, the accumulated OH-CATH aggregated and damaged the bacteria membrane in a pore-forming manner, the average pore size of $E$. coli treated by $\mathrm{OH}-\mathrm{CATH}$ was measured to be around 100-300 nm. In the last step, with the damage of cell permeability, the contents of the cells were released and the cells eventually collapsed.

Tab. 1 Escherichia coli ATCC 25922 growth kinetics at $\mathrm{OD}_{600 \mathrm{~nm}}$

\begin{tabular}{ccccccc}
\hline Samples & 0 & $0.5 \mathrm{~h}$ & $1 \mathrm{~h}$ & $2 \mathrm{~h}$ & $6 \mathrm{~h}$ & $21 \mathrm{~h}$ \\
\hline OH-CATH treated & 0.708 & 0.760 & 0.804 & 0.852 & 1.141 & 1.678 \\
Without OH-CATH & 0.708 & 1.104 & 1.340 & 1.548 & 1.906 & 2.506 \\
\hline
\end{tabular}



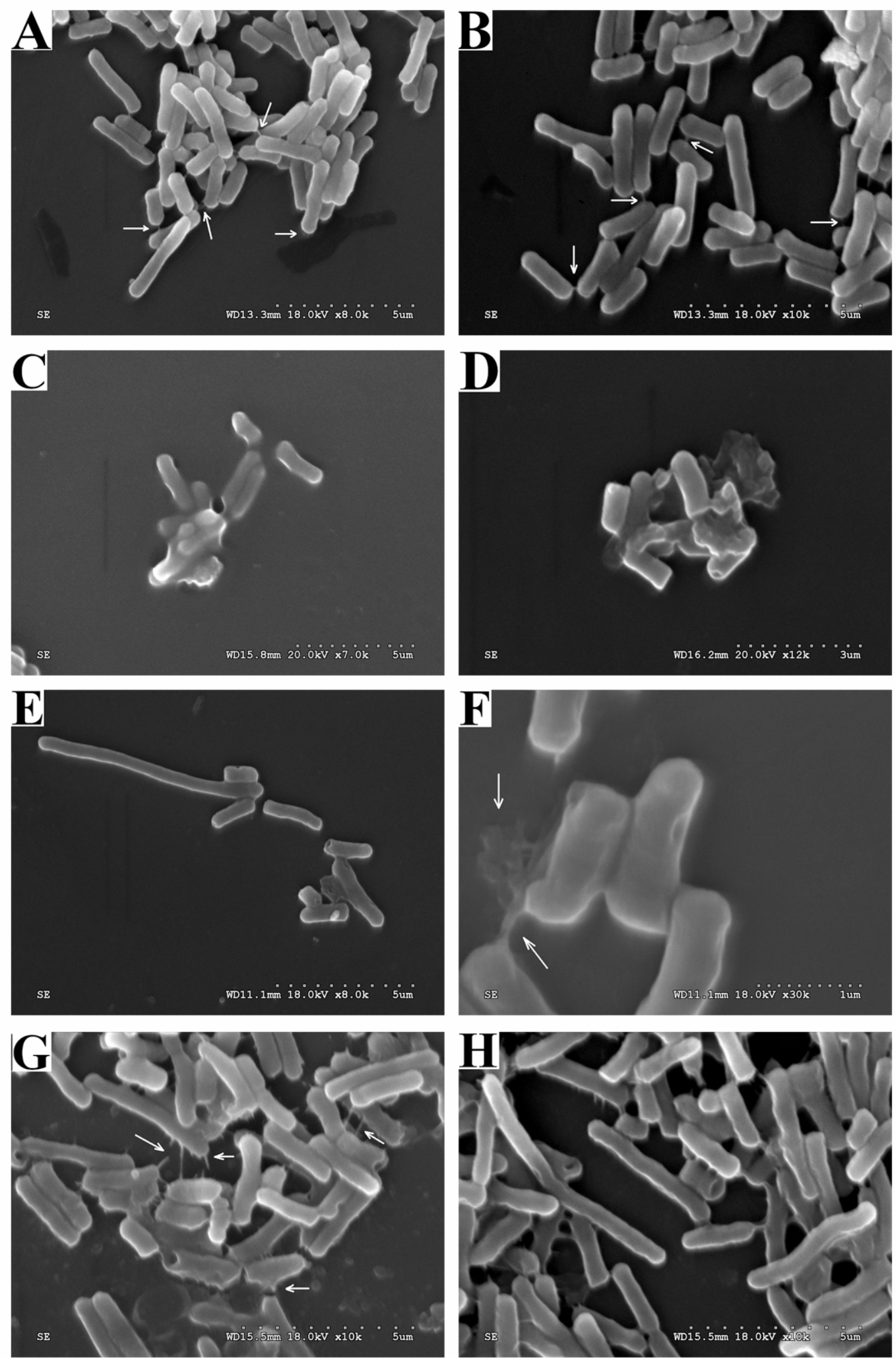

Fig. 1 SEM images of Escherichia coli ATCC 25922 treated with OH-CATH for different times (A-B) At zero time, no OH-CATH added. (C) 1 hour after OH-CATH treated. (D) 2 hours after OH-CATH treated. (E-F) 6 hours after $\mathrm{OH}-\mathrm{CATH}$ treated. $(\mathrm{G}-\mathrm{H}) 21$ hours after $\mathrm{OH}-\mathrm{CATH}$ treated. 

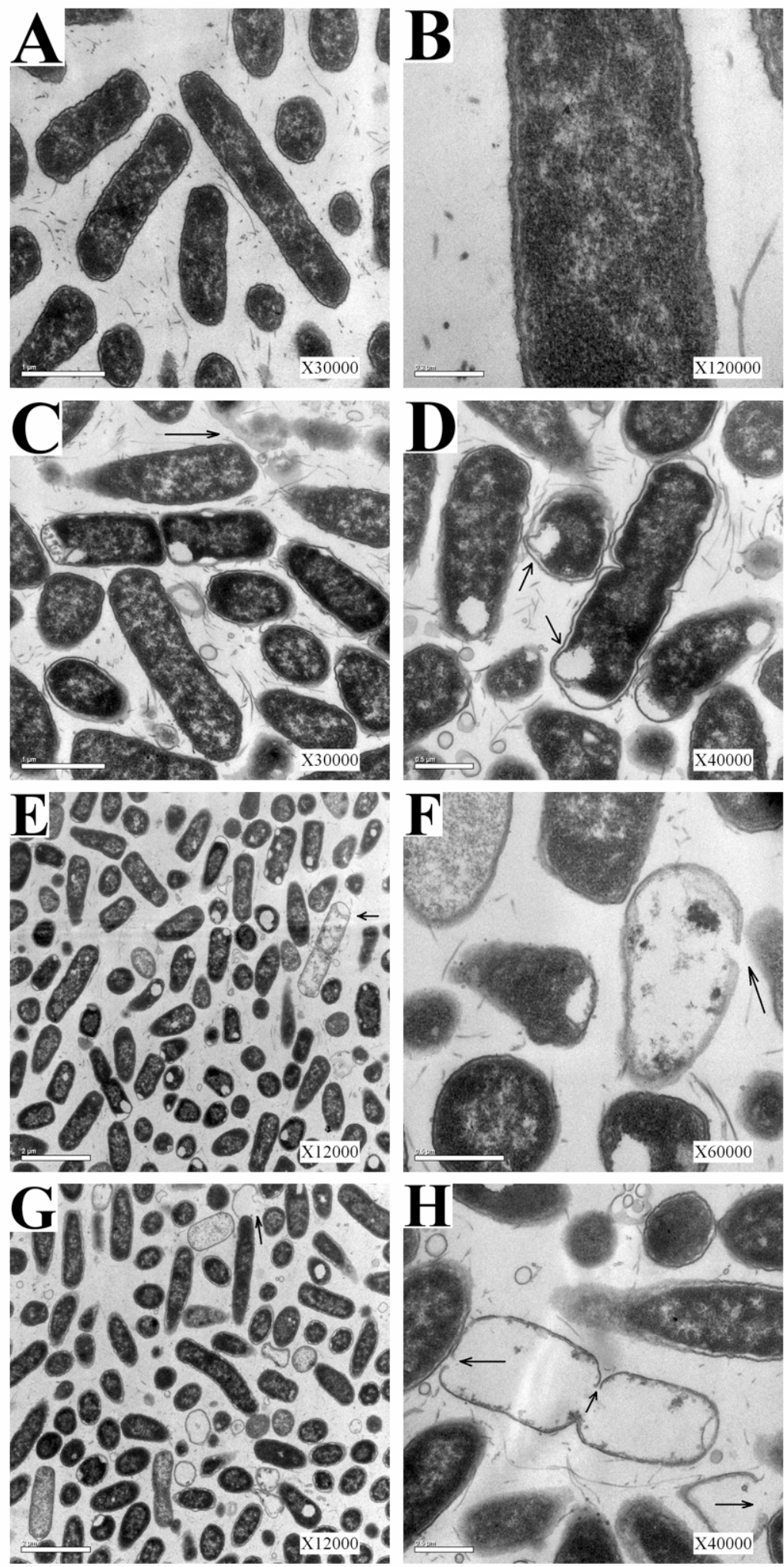

Fig. 2 TEM images of Escherichia coli ATCC 25922 treated with OH-CATH for different times (A-B) At zero time, no OH-CATH added. (C-D) 2 hours after OH-CATH treated. (E-F) 6 hours after OH-CATH treated. (G-H) 21 hours after $\mathrm{OH}-\mathrm{CATH}$ treated. 


\section{References:}

Bals R, Wilson JM. 2003. Cathelicidins - a family of multifunctional antimicrobial peptides[J]. Cell Mol Life Sci, 60: 711-720.

Boman HG. 1991. Antibacterial peptides: key components needed in immunity[J]. Cell, 65: 205-207.

Boman HG. 1995. Peptide antibiotics and their role in innate immunity[J]. Annu Rev Immunol, 13: 61-92.

Broekaert WF, Terras FR, Cammue BP, Osborn RW. 1995. Plant defensins: novel antimicrobial peptides as components of the host defense system[J]. Plant Physiol, 108: 1353-1358.

Chang CI, Pleguezuelos O, Zhang YA, Zou J, Secombes CJ. 2005. Identification of a novel cathelicidin gene in the rainbow trout, Oncorhynchus mykiss[J]. Infect Immun, 73: 5053-64.

Chang CI, Zhang YA, Zou J, Nie P, Secombes CJ. 2006. Two cathelicidin genes are present in both rainbow trout (Oncorhynchus mykiss) and atlantic salmon (Salmo salar) [J]. Antimicrob Agents Chemother, 50:185-195.

da Silva A, Teschke O. 2003. Effects of the antimicrobial peptide PGLa on live Escherichia coli[J]. Biochim Biophys Acta, 1643: 95-103.

Goitsuka R, Chen CL, Benyon L, Asano Y, Kitamura D, Cooper MD. 2007. Chicken cathelicidin-B1, an antimicrobial guardian at the mucosal M cell gateway[J]. Proc Natl Acad Sci USA, 104: 15063-8.

Hancock RE, Lehrer R. 1998. Cationic peptides: a new source of antibiotics[J]. Trends Biotechnol, 16: 82-88.

Harder J, Bartels J, Christophers E, Schröder JM. 1997. A peptide antibiotic from human skin[J]. Nature, 387: 861 .

Lee WH, Zhang J, Zhang YX, Jin Y, Lai R, Zhang Y. 2005. Maximin 9, a novel free thiol containing antimicrobial peptide with antimycoplasma activity from frog Bombina maxima[J]. FEBS Lett, 579: 4443-4448.

Lehrer RI, Ganz T. 2002. Cathelicidins: a family of endogenous antimicrobial peptides[J]. Curr Opin Hematol, 9: 18-22.

Li A, Lee PY, Ho B, Ding JL, Lim CT. 2007. Atomic force microscopy study of the antimicrobial action of Sushi peptides on Gram negative bacteria[J]. Biochim Biophys Acta, 1768: 411-418.

Li P, Chan HC, He B, So SC, Chung YW, Shang Q, Zhang YD, Bensch KW, Raida M, Magert HJ, Schulz-knappe P, Forssmann WG. 1995. hBD-1: a novel beta-defensin from human plasma[J]. FEBS Lett, 368: 331-335.

Li P, Chan HC, He B, So SC, Chung YW, Shang Q, Zhang YD, Zhang YL. 2001. An antimicrobial peptide gene found in the male reproductive system of rats[J]. Science, 291: 1783-1785.

Matsuzaki K, Sugishita K, Harada M, Fujii N, Miyajima K. 1997. Interactions of an antimicrobial peptide, magainin 2, with outer and inner membranes of Gram-negative bacteria[J]. Biochim Biophys Acta, 1327: 119-130.

Nicolas P, Mor A. 1995. Peptides as weapons against microorganisms in the chemical defense system of vertebrates[J]. Annu Rev Microbiol, 49: 277-304.

Uzzell T, Stolzenberg ED, Shinnar AE, Zasloff M. 2003. Hagfish intestinal antimicrobial peptides are ancient cathelicidins $[\mathrm{J}]$. Peptides, 24: 1655-1667.

Vizioli J, Salzet M. 2002. Antimicrobial peptides from animals: focus on invertebrates[J]. Trends Pharmacol Sci, 23: 494-496.

Xiao Y, Cai Y, Bommineni YR, Fernando SC, Prakash O, Gilliland SE, Zhang G. 2006. Identification and functional characterization of three chicken cathelicidins with potent antimicrobial activity[J]. $J$ Biol Chem, 281: v2858-2867.

Zanetti M, Del Sal G, Storici P, Schneider C, Romeo D. 1993. The cDNA of the neutrophil antibiotic Bac5 predicts a pro-sequence homologous to a cysteine proteinase inhibitor that is common to other neutrophil antibiotics[J]. J Biol Chem, 268: 522-526.

Zanetti M, Gennaro R, Romeo D. 1995. Cathelicidins: a novel protein family with a common proregion and a variable C-terminal antimicrobial domain[J]. FEBS Lett, 374: 1-5.

Zanetti M, Litteri L, Gennaro R, Horstmann H, Romeo D. 1990. Bactenecins, defense polypeptides of bovine neutrophils, are generated from precursor molecules stored in the large granules $[\mathrm{J}]$. J Cell Biol, 111: 1363-1371.

Zasloff, M. 1992. Antibiotic peptides as mediators of innate immunity[J]. Curr Opin Immunol, 4: 3-7.

Zhao H, Lee WH, Shen JH, Li H, Zhang Y. 2008a. Identification of novel semenogelin I-derived antimicrobial peptide from liquefied human seminal plasma [J]. Peptides, 29: 505-511.

Zhao H, Liu XD, Gao ZH, Zhang JH, Li H, Zhang Y, Lee WH, Shen JH. 2008b. Expression of human semenogelin I-52 and antibacterial activity investigation of recombinant peptide [J]. Zool Res, 29: 139-144.

Zhao H, Gan TX, Liu XD, Jin Y, Lee WH, Shen JH, Zhang Y. 2008c. Identification and characterization of novel reptile cathelicidins from elapid snakes[J]. Peptides, 29: 1685-1691. 